\title{
Recent radiation in a marine and freshwater dinoflagellate species flock
}

\author{
Nataliia V Annenkova ${ }^{1,2}$, Gert Hansen ${ }^{3}$, Øjvind Moestrup ${ }^{3}$ and Karin Rengefors ${ }^{2}$ \\ ${ }^{1}$ Limnological Institute, Siberian Branch of the Russian Academy of Sciences, Irkutsk, Russia; ${ }^{2}$ Aquatic \\ Ecology, Department of Biology, Lund University, Lund, Sweden and ${ }^{3}$ Marine Biological Section, Department \\ of Biology, University of Copenhagen, Copenhagen, Denmark
}

\begin{abstract}
Processes of rapid radiation among unicellular eukaryotes are much less studied than among multicellular organisms. We have investigated a lineage of cold-water microeukaryotes (protists) that appear to have diverged recently. This lineage stands in stark contrast to known examples of phylogenetically closely related protists, in which genetic difference is typically larger than morphological differences. We found that the group not only consists of the marine-brackish dinoflagellate species Scrippsiella hangoei and the freshwater species Peridinium aciculiferum as discovered previously but also of a whole species flock. The additional species include Peridinium euryceps and Peridinium baicalense, which are restricted to a few lakes, in particular to the ancient Lake Baikal, Russia, and freshwater S. hangoei from Lake Baikal. These species are characterized by relatively large conspicuous morphological differences, which have given rise to the different species descriptions. However, our scanning electron microscopic studies indicate that they belong to a single genus according to traditional morphological characterization of dinoflagellates (thecal plate patterns). Moreover, we found that they have identical SSU (small subunit) rDNA fragments and distinct but very small differences in the DNA markers LSU (large subunit) rDNA, ITS2 (internal transcribed spacer 2) and СОВ (cytochrome $b$ ) gene, which are used to delineate dinoflagellates species. As some of the species co-occur, and all four have small but species-specific sequence differences, we suggest that these taxa are not a case of phenotypic plasticity but originated via recent adaptive radiation. We propose that this is the first clear example among free-living microeukaryotes of recent rapid diversification into several species followed by dispersion to environments with different ecological conditions.
\end{abstract}

The ISME Journal (2015) 9, 1821-1834; doi:10.1038/ismej.2014.267; published online 20 January 2015

\section{Introduction}

During the past decade, our understanding of microbial diversity and biogeography has improved enormously (Martiny et al., 2006). However, the mechanisms that promote the diversification of freeliving unicellular eukaryotes (protists) have to date been insufficiently studied. Rapid adaptive radiation could be one of the main mechanisms of organism diversification (Schluter, 2000). It refers to the rapid diversification of lineages leading to evolution of phenotypic diversity followed by adaptation into various niches (for example, Schön and Martens, 2004). Our understanding of speciation and population divergence is, however, based mainly on studies of multicellular organisms owing to historical reasons. For instance, our knowledge about adaptive radiation is based on

Correspondence: NV Annenkova, Limnological Institute, Siberian Branch of the Russian Academy of Sciences, 3, Ulan-Batorskaya, Irkutsk 664033, Russia.

E-mail: n_annenkova@lin.irk.ru or tasha.annenkova@gmail.com Received 6 August 2014; revised 3 December 2014; accepted 12 December 2014; published online 20 January 2015 such classic systems as cichlids from Lake Tanganyika (Seehausen, 2006) and Darwin's finches on the Galapagos islands (Grant and Grant, 2011). Currently, a very popular model system is the three-spined stickleback fish complex, an originally marine species that has colonized freshwaters and diversified into a flock of partially coexisting freshwater species during the past ice age (Jones et al., 2012). Together these examples exhibit an exceptional extent of adaptive diversification to a variety of ecological niches.

Similar studies are largely lacking among microorganisms, except for numerous laboratory studies on the diversification process in bacterial consortia (reviewed in MacLean, 2005). In particular, Gómez and Buckling (2013) suggested that rapid diversification is much greater in the absence of an established natural microbial community based on their work on the soil bacterium Pseudomonas fluorescens. Hunt et al. (2008) showed sympatric differentiation in marine bacteria, which they attribute to horizontal gene transfer and adaptation. Speciation theory presently contains different models of adaptive radiation, including 'invasion 
of empty niches', 'spontaneous clusterization' and 'sympatric diversification' models (Pfennig et al., 2010). However, Gavrilets and Losos (2009) noted that 'how exactly radiation occurs, and how it differs among taxa and in different settings, as well as why some lineages radiate and others do not, are still unclear'. The term 'rapid adaptive radiation' is nevertheless widely discussed and there are no reliable quantitative criteria. Wilke et al. (2010) suggest that a rapid radiation is a monophyletic group of at least three species that have evolved during a short time with a few consecutive speciation events.

Some protists seem to speciate via rapid radiation as in the symbiotic dinoflagellates (LaJeunesse, 2005) and pathogenic fungi (Kasuga et al., 2003). However, this phenomenon is still poorly studied, and there is a lack of examples both in nature and laboratory experiments. Thus finding and investigating cases of recent rapid radiation among protists is much needed.

A case of recent diversification following the transition from marine to freshwater has been proposed for two species of dinoflagellates, Scrippsiella hangoei and Peridinium aciculiferum (Logares et al., 2007a). S. hangoei, known from the Baltic Sea, can grow in salinities up to $30 \%$, while $P$. aciculiferum is a freshwater species found in lakes (Logares et al., 2007a). Moreover, S. hangoei was shown not to cluster with confirmed Scrippsiella species. The two species are morphologically distinct but show no difference in the ribosomal DNA markers traditionally used for species delimitation (Logares et al., 2007a, 2008). Later, S. aff. hangoei was discovered in Antarctic brackish lakes, showing identical morphology with $S$. hangoei from the Baltic Sea but with small differences in the rDNA markers (Rengefors et al., 2008). Recently, small subunit (SSU) rDNA fragments similar to the $S$. hangoei/P. aciculiferum sequences were discovered in environmental DNA samples from Lake Baikal (Annenkova and Belikov, 2010; Annenkova et al., 2011). However, it was not possible to determine from which species these fragments originated, as the data were acquired from total DNA of an environmental sample and not from the individual organisms. Either the fragments originated from one or both of these species or they belonged to yet another closely related species. Previous studies from Baikal show that a number of different dinoflagellates, including the endemic Peridinium baicalense, are present in the lake although there is no previous reference to $P$. aciculiferum or $S$. hangoei in open Baikal waters (Tanichev and Bondarenko, 1995).

Lake Baikal is situated in Eastern Siberia, Russia and is the oldest ( $>25$ million years) and the deepest (about $1637 \mathrm{~m}$ ) lake on Earth (Mats et al., 2011). Lake Baikal contains around 1600 endemic species (Timoshkin, 1999) and is a hotspot of adaptive radiation for several groups of multicellular taxa (Sherbakov, 1999). Because of its long history, the lake contains species that belong both to very ancient lineages and to recent invasions, for example, the neoendemic Baikal seal (Harington, 2008).

The aim of the current study was to explore the patterns of genetic and morphological diversity in the species complex comprising the dinoflagellates $P$. aciculiferum $/ S$. hangoei to gain understanding on how these species have evolved and to determine whether their divergence is recent or ancient. Our approach was to analyze dinoflagellates from Lake Baikal and other lakes in Europe and Sibieria and to compare those with other dinoflagellate lineages. To this end, we performed single-cell PCR on a set of molecular markers in combination with detailed scanning electron microscopy (SEM) of the morphology. An advantage of this method is that molecular genetic variation can be observed without introducing artifacts from culturing.

\section{Methods}

\section{Collection sites}

All samples were collected during March-May 2011 from ice-covered freshwater lakes in the Baikal region, Russia (Figure 1) and in Lake Erken, located $15 \mathrm{~km}$ from the Baltic Sea in Sweden (see Table 1 for lake descriptions). The samples were collected by towing surface water using a plankton net $(10-\mu \mathrm{m}$ mesh size) after drilling of holes in the ice. In Lake Baikal, samples were also taken by a scubadiver, who collected visible dinoflagellate patches using a syringe. Unicellular cultures of $S$. hangoei (Lake Baikal), P. baicalense (Lake Baikal) and P. aciculiferum (Lake Tovel) were cultured in modified Woods Hole medium (salinity, 0) based on Milli-Q

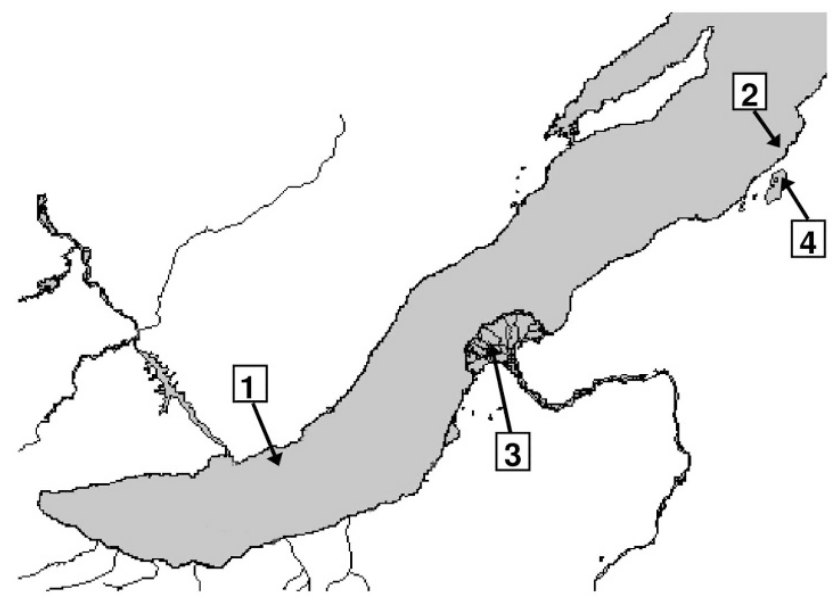

Figure 1 Collecting sites in the Baikal region: 1-Lake Baikal, west coast of the south basin, 2-Lake Baikal, east coast of the central basin, 3-Lake Zavernyaikha, which is located $7 \mathrm{~km}$ from the east coast of Lake Baikal in the Selenga delta, 4-Lake Kotokel, which is connected to Lake Baikal (water flows both ways), but separated by a low mountain chain ( $5 \mathrm{~m}$ above Baikal level). 
Table 1 Description of the studied lakes

\begin{tabular}{|c|c|c|c|c|}
\hline $\begin{array}{l}\text { Name of the water } \\
\text { reservoir }\end{array}$ & $\begin{array}{l}\text { Coordinates of the } \\
\text { sampling }\end{array}$ & Time of the sampling & Trophic level & $\begin{array}{l}\text { Average depth } \\
\text { of the lake }\end{array}$ \\
\hline Lake Baikal & $\begin{array}{l}\text { (1) } N-51^{\circ} 33^{\prime} E-105^{\circ} 6^{\prime} \text {, } \\
\text { west coast, south basin } \\
\text { (2) N-52 } 52^{\circ} 56^{\prime} \text { E- } 108^{\circ} 12^{\prime}, \\
\text { east coast, central basin }\end{array}$ & $\begin{array}{l}\text { (1) Each week from } 3 \text { March till } 27 \text { April } \\
2011 \text { (50, } 250 \text { and } 1050 \text { m from the coast) } \\
\text { (2) Littoral zone on } 1-2 \text { May } 2011\end{array}$ & Oligotrophic & $744 \mathrm{~m}$ \\
\hline Lake Zavernyaikha & $\mathrm{N}-52^{\circ} 25^{\prime} \mathrm{E}-106^{\circ} 35^{\prime}$ & 5 March 2011 & $\begin{array}{l}\text { Hypertrophic in winter, } \\
\text { mesotrophic in other time }\end{array}$ & $\begin{array}{c}\text { Not exceeding } \\
4 \mathrm{~m}\end{array}$ \\
\hline Lake Kotokel & $\mathrm{N}-52^{\circ} 48^{\prime} \mathrm{E}-108^{\circ} 7^{\prime}$ & 1 May 2011 & Eutrophic & $3.5 \mathrm{~m}$ \\
\hline Lake Erken & $\mathrm{N}-59^{\circ} 25^{\prime} \mathrm{E}-18^{\circ} 15^{\prime}$ & The end of April 2012 and 2013 & Eutrophic & $9 \mathrm{~m}$ \\
\hline
\end{tabular}

water (Millipore Corp., Bedford, MA, USA). Cultures were kept in an incubator at $4 \pm 1{ }^{\circ} \mathrm{C}$, $20 \mu \mathrm{mol}$ photons $\mathrm{m}^{-2} \mathrm{~s}^{-1}$, and $12: 12 \mathrm{~h}$ light-dark cycle.

\section{Single-cell PCR and sequencing}

Volumes of $30 \mu \mathrm{l}$ field sample preserved in $70 \%$ ethanol or $1 \%$ Lugol's iodine were transferred to a drop of deionized water on an autoclaved glass slide. Individual intact dinoflagellate cells were isolated and photographed using a Nikon Eclipse TS100 microscope (Nikon Corporation, Tokyo, Japan) at $\times 100$ magnification. Each cell was washed in 6-8 droplets of deionized MilliQ water using a sterile micropipette to prevent contamination with foreign DNA. Negative PCR controls were done using the last droplet as a template, which might contain non-target dinoflagellate DNA (see agarose gel in Supplementary Figure S1). After the washing procedure, individual cells were transferred to a $4-\mu l$ deionized water droplet and broken with a fine glass needle. The entire ruptured cell was transferred to a tube and placed at $-80^{\circ} \mathrm{C}$ overnight.

Dinoflagellate-specific PCR primers were designed or retrieved from our previous studies for partial SSU and large subunit (LSU) rDNA, internal transcribed spacer 2 (ITS2) and partial cytochrome $b$ (COB) gene (Supplementary Table S1). The specificity of the primers was checked against known dinoflagellate sequences using the Primer Blast program (http://www.ncbi.nlm.nih.gov/tools/primerblast/). The relatively conservative SSU rDNA fragment is the most studied molecular marker among dinoflagellates. LSU rDNA has been successfully used for dinoflagellate species separation (Daugbjerg et al., 2000). The mitochondrial COB gene has been suggested for dinoflagellate barcoding (Lin et al., 2009). ITS2 sequences are highly variable and useful to delineate closely related species of dinoflagellates (Montresor et al., 2003; Litaker et al., 2007).

SSU rDNA fragments $(1179 \mathrm{bp}$, including the variable V4 domain) were amplified and sequenced for five replicate cells of $P$. baicalense (Baikal), four replicates of Peridinium euryceps (Baikal and Erken) and two replicates of $P$. aciculiferum (Kotokel and Erken). DNA fragments containing partial 5.8S rDNA and ITS2 (250 bp) and LSU rDNA (1045 bp, including the variable D1-D3 domains) were amplified and sequenced from seven replicate cells of $P$. baicalense (Baikal), six replicates of $P$. euryceps (three from Baikal and three from Erken), three replicates of $P$. aciculiferum (Kotokel and Erken) and two replicates of $S$. hangoei (Lake Baikal) (see details in Figure 2 and Supplementary Table S2). Mitochondrial COB DNA fragments (590 bp) were sequenced from three cells of $P$. baicalense, two cells of $P$. euryceps from Lake Baikal and one cell of $P$. euryceps from Lake Erken. Cells of $S$. hangoei were rare in our lake samples, thus we cultivated it and sequenced the COB mtDNA fragment from this culture.

PCR reactions using the entire ruptured dinoflagellate cells were performed using a $2 \times$ PCR Master Mix with high-fidelity DNA polymerase (Phusion, Finnzyme, Espoo, Finland) and $0.4 \mu \mathrm{M}$ of each primer. To amplify SSU rDNA and ITS2-LSU rDNA fragments from one cell, multiplex PCR was performed with L1 and Dino1662R and 5L and R28Lo primers simultaneously. Thermocycling was as follows: initially $98{ }^{\circ} \mathrm{C}$ for $1 \mathrm{~min}$, followed by 33 cycles of $98^{\circ} \mathrm{C}(10 \mathrm{~s}), 68^{\circ} \mathrm{C}(30 \mathrm{~s}), 72^{\circ} \mathrm{C}(45 \mathrm{~s})$, and then finally $72{ }^{\circ} \mathrm{C}(5 \mathrm{~min})$. The second PCR was done with each of the primer pairs separately, with $0.6 \mu \mathrm{l}$ of the first PCR reaction used as a template. For the PCR of the COB mtDNA fragment, cycling conditions were the same as for rDNA markers but the annealing temperature was $66^{\circ} \mathrm{C}$. The total volume of each PCR reaction was analyzed by electrophoresis on a $1.5 \%$ agarose gel stained with GelRed Nucleic Acid Gel Stain (Biotium Inc., Hayward, CA, USA) in $0.5 \times$ TBE (Tris-Borate-EDTA) buffer. PCR products were excised from the gel and sequenced from both sides using the BigDye system (Perkin Elmer, Waltham, MA, USA), followed by electrophoresis using an Automated Sequencer (BaseStation, MJ Research, Waltham, MA, USA).

Single-cell PCRs of the ITS2 fragment were also repeated using the live cells of $P$. baicalense and $P$. euryceps in Russia. These sequences were deposited to GenBank under Accession Numbers KJ450981-KJ450992 and KF446621-KF446624.

\section{Alignment and phylogenetic analyses}

The obtained sequences were edited manually and assembled using BioEdit v7.1.3 (Hall, 1999). DNA 


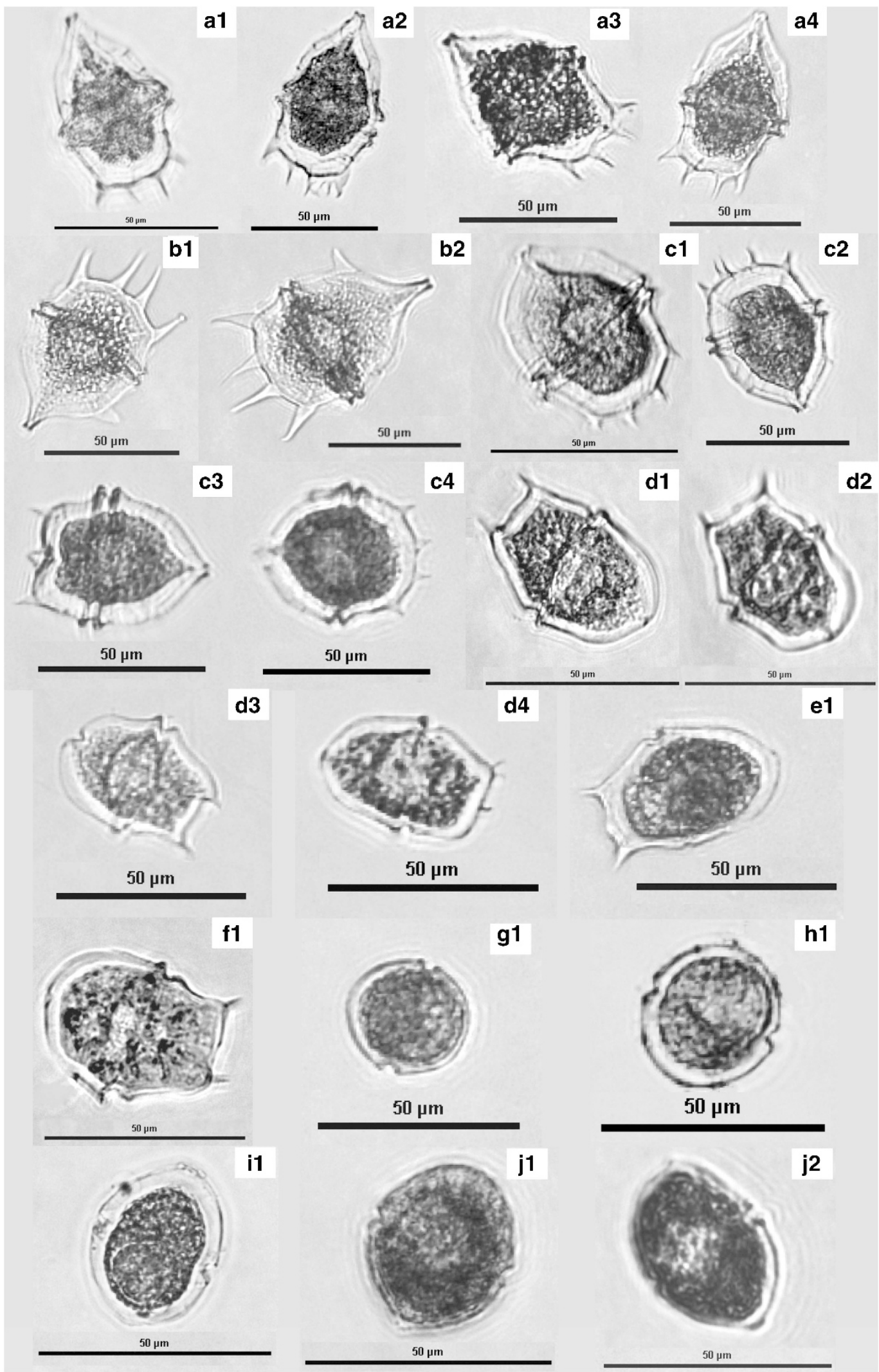

Figure 2 Some of the dinoflagellates cells used for single-cell PCR analysis and sequencing. A1-A4-Peridinium baicalense from Baikal east coast, B1-B2-P. baicalense from Baikal west coast, C1-C4-P. baicalense from Zavernyaikha; D1-E1-Peridinium euryceps from Baikal west and east coasts, F1-P. euryceps from Erken; G1 and H1-Scrippsiella hangoei from Baikal west and east coasts, I1Peridinium aciculiferum from Kotokel, J1 and J2-P. aciculiferum from Erken. 
sequences of both $S$. hangoei from the Baltic Sea, Arctic Ocean and Antarctic lakes and P. aciculiferum from European lakes were obtained previously (from Logares et al., 2008) and used for comparison with the newly obtained sequences. Separate alignments were constructed for ITS2-LSU rDNA and COB DNA fragments using BioEdit v7.1.3 (Hall, 1999). Analysis of the genetic differences between the sequences was performed with MEGA v.5.1 (Tamura et al., 2011). ITS2 secondary structures were predicted by homology modeling using the ITS2 Database (http://its2.bioapps.biozentrum. uni-wuerzburg.de/), with the secondary structure of Baltic S. hangoei ITS2 as a template. CBCAnalyzer (Wolf et al., 2005) was used to detect compensatory base changes and build the ITS2 phylogram.

A BLAST search was performed to find related sequences of other dinoflagellates in GenBank. A SSU-LSU rDNA alignment was constructed using Mafft v6.952 based on the G-INS-I model with default parameters (Katoh and Toh, 2010). The alignment was manually edited. Due to ambiguous alignment of the highly divergent domain D2 in LSU rDNA, this domain was excluded, thus leaving 1791 sites (without gaps) in 59 sequences for phylogenetic inference.

The Bayesian information criterion implemented in jModelTest 2.1.1 (Darriba et al., 2012) indicated that the General Time Reversible model of nucleotide substitution, with Gamma (G) distributed rates across sites and a proportion of invariable sites (I), was the most appropriate evolutionary model for the SSU-LSU rDNA alignment. Phylogenies of these sequences were constructed based on this model using the Bayesian inference (BI) and Maximum Likelihood (ML) analyses.

BI analysis was conducted with MrBayes-3.1.2 (Ronquist and Huelsenbeck, 2003) and was run with seven Markov chains (six heated chains, one cold) for two $10^{6}$ generations and two independent runs in each analysis. Trees were sampled every hundredth generation, the first $25 \%$ samples were discarded as 'burn-in'. The average s.d. of split frequencies, convergence diagnostics for the posterior probabilities of bipartitions (Stdev(s)) and branch lengths (potential scale reduction factor of Gelman and Rubin (1992) were used to check for convergence.

$\mathrm{ML}$ analysis was conducted using the morePhyMl and PhyMl (http://mobyle.pasteur.fr) as well as the RaxML (http://www.phylo.org/) online programs. The best likelihood score was obtained with morePhyMl, and this tree was used further. Its script performs ratchet-based ML tree searches, which is an efficient way to avoid local optima (Criscuolo, 2011). A subtree-pruning-regrafting first tree swapping algorithm was used. A non-parametric branch support test based on a Shimodaira-Hasegawa-like procedure (SH test) (Anisimova and Gascuel, 2006) was performed to test the statistical significance of specific topological relationship. To test the statistical difference between marine and freshwater
Thoracosphaeraceae-like species, a Unifrac test was used (Lozupone et al., 2006). Each sequence was treated as marine, brackish or freshwater. Additional analyses were carried out with two groups: marine-brackish and freshwater sequences.

The statistical support values were drawn on the best scoring ML tree visualized in FigTree v1.4.0 (http://tree.bio.ed.ac.uk/).

\section{Microscopy and morphological measurements}

Cell length and width were determined from measurements of 20 cells of each species fixed in Lugol's iodine, by using a Nikon Eclipse light microscope at $\times 400$ magnification. Spines were not taken into account. A one-way analysis of variance was performed using Microsoft Excel 2007 (Redmond, WA, USA) to determine statistical significance among mean length/width ratios of the different species.

Baikal net samples with numerous dinoflagellate cells were used for SEM. In addition, photographs from a culture of $P$. aciculiferum strain SCCAP K-0099 was included for comparison. Cells from the Lake Baikal were either fixed in 1\% Lugol's iodine or $70 \%$ ethanol and stored at $4{ }^{\circ} \mathrm{C}$ until further processing for SEM. The culture from Lake Tovel was fixed for $50 \mathrm{~min}$ in a mixture of $\mathrm{OsO}_{4}$ and saturated $\mathrm{HgCl}_{2}$ at a final concentration of $0.6 \%$ and $10 \%$, respectively. Fixed material was prepared as described elsewhere (Hansen and Flaim, 2007) and examined using a JEOL JSM-6335F field emission SEM (JEOL Ltd, Tokyo, Japan).

\section{Results}

Species occurrence

P. baicalense (Figure 2, A1-B2), P. euryceps (Figure 2, D1-E1) and S. hangoei (Figure 2, G1, H1) were all found concurrently in the Lake Baikal open waters. Cells of $P$. baicalense were also found in Lake Zavernyaikha (Figure 2, C1-C4), which is hydrologically connected to the west coast of Lake Baikal. Cells of $P$. euryceps were also found in Lake Erken (Sweden) (Figure 2, F1) where it was first described (Rengefors and Meyer, 1998).

$P$. aciculiferum, which is common in many cold freshwater lakes (for example, Logares et al., 2008), was observed in the lakes near Lake Baikal, in particular in Lake Kotokel (Figure 2, I1). Lake Kotokel's phytoplankton community is typical of the Siberian region but differs from that of Lake Baikal open waters (Popovskaya, 1991). We did not find $P$. aciculiferum in the samples collected in Lake Baikal open waters nor in Lake Zavernyaikha. However, $P$. aciculiferum has been previously observed in shallow Baikal bays (regions of the lake inhabited by various cosmopolitan organisms; Kozhova and Izmest'eva, 1998). All the confirmed occurrences of dinoflagellates of the aciculiferum/ 
hangoei complex included in this study are listed in Table 2.

\section{Morphological diversity}

Based on 20 cells from each species, we determined general morphology of the studied species and measured their size (length and width) and calculated the relative length (Table 3). Detailed descriptions of the species were done based on SEM data.

All studied morphospecies ( $P$. baicalense, $P$. euryceps, $P$. aciculiferum, $S$. hangoei) have identical plate formulas (used to delineate thecate dinoflagellates microscopically): po, x, 4', 7', 3a, 6c, ?s, 5",' 2,"' (Figures 3-5). Detailed observations of $P$. baicalense was made here for the first time and showed that the number of thecal plates was misinterpreted when it was first described (Kisselew and Zwetkow, 1935). This is most likely caused by the very wide intercalary growth bands and distinct lists or flanges on the plates.

There are evident differences in the general morphology of all four species (Figures 2-5) despite their identical plate formulas. The cells differ both in size and relative length (Table 3 ), in the shape of the thecal plates and in the general cell shape. $P$. baicalense is the biggest and the most elongated morphospecies, though its variants from Lake Zavernyaikha and from the east coast of the Baikal South Basin (Figure 2, A1-A4) are rounder. There are no spines on $S$. hangoei cells, while cells of $P$. aciculiferum have 3-4 small antapical spines (Figure 5). Cells of P. euryceps have two pronounced antapical spines (Figure 4). Each of the two antapical plates of $P$. baicalense cells is furnished with two prominent horns, which are sometimes bifurcated and may even fuse with each other (Figure 3a). Additionally, this species has a characteristic more or less pronounced lateral horn on one side (Figure 3).

Cultures of $P$. baicalense and $S$. hangoei from the Lake Baikal were monitored during 2 years, and no changes in the morphology were found except that the spines of $P$. baicalense were shorter in culture than they usually are in nature. Previous observations also showed a stable morphology of $P$. aciculiferum and Baltic $S$. hangoei in culture (Logares et al., 2008).

Nuclear rDNA and mitochondrial COB gene variations
among species variants All the SSU rDNA fragments of the studied species were identical to each other, except Antarctic Scrippsiella aff. Hangoei, which had one substitution in this fragment.

Very little difference was found within the 5.8 S-ITS2-LSU rDNA fragments among the different lineages. The ITS2 DNA sequences from all Lake Baikal dinoflagellates and $P$. euryceps from Lake Erken were identical to each other and differed from freshwater $P$. aciculiferum (both from Lake Erken and Lake Kotokel) in one substitution. The partial LSU rDNA sequences (1045 bp) of all the Lake Baikal dinoflagellates and the $P$. aciculiferum obtained in this study contained three variable sites and one single-nucleotide polymorphism. Comparison of these sequences with sequences of $P$. aciculiferum and $S$. hangoei available from GenBank (224 bp of ITS2 and 548 bp of LSU rDNA)

Table 2 Confirmed occurrence of morphospecies

\begin{tabular}{lccccccc}
\hline Morphospecies & $\begin{array}{c}\text { Lake Baikal } \\
\text { (freshwater) }\end{array}$ & $\begin{array}{c}\text { Lake Kotokel } \\
\text { (freshwater) }\end{array}$ & $\begin{array}{c}\text { Lake Zavernyai- } \\
\text { kha(freshwater) }\end{array}$ & $\begin{array}{c}\text { Lake Erken } \\
\text { (freshwater) }\end{array}$ & $\begin{array}{c}\text { Lake Tovel } \\
\text { (freshwater) }^{a}\end{array}$ & $\begin{array}{c}\text { Baltic Sea } \\
\text { (brackish) }^{a}\end{array}$ & $\begin{array}{c}\text { Vereteno and Highway } \\
\text { Antarctic lakes (brackish) }\end{array}$ \\
\hline $\begin{array}{l}\text { S. hangoei } \\
\begin{array}{l}\text { P. aciculiferum } \\
\text { P. baicalense }\end{array}\end{array}$ & $\mathrm{x}$ & $\mathrm{x}$ & $\mathrm{x}$ & $\mathrm{x}$ & $\mathrm{x}$ & $\mathrm{x}$ & $\mathrm{x}$ \\
\begin{tabular}{l} 
P. euryceps \\
\hline
\end{tabular} & $\mathrm{x}$ & & $\mathrm{x}$ & $\mathrm{x}$ & & \\
\hline
\end{tabular}

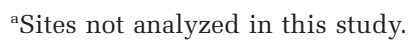

Table 3 Size of the dinoflagellate cells (based on 20 cells)

\begin{tabular}{|c|c|c|}
\hline Species name & Mean size $\mu \mathrm{m}$ width $\times$ length & Mean length/width ratio \\
\hline Scrippsiella hangoei (Baltic Sea) ${ }^{\mathrm{a}}$ & $20.24 \times 23.00$ & 1.14 \\
\hline Scrippsiella hangoei (Lake Baikal) & 26.96 (s.d. 2.90$) \times 33.33$ (s.d. 3.66) & 1.24 (s.d. 0.06) \\
\hline Peridinium aciculiferum ( Lake Erken) ${ }^{\mathrm{a}}$ & $28.63 \times 38.41$ & 1.35 \\
\hline Peridinium aciculiferum (Lake Kotokel) & 26.77 (s.d. 2.62$) \times 37.12$ (s.d. 2.26) & 1.39 (s.d. 0.12) \\
\hline Peridinium euryceps (Lake Baikal) & 27.05 (s.d. 1.27$) \times 43.21$ (s.d. 3.18$)$ & 1.59 (s.d. 0.11) \\
\hline Peridinium baicalense (Lake Zavernyaikha) & 34.69 (s.d. 1.96) × 49.62 (s.d. 3.20$)$ & 1.43 (s.d. 0.06) \\
\hline Peridinium baicalense (Lake Baikal) & 35.12 (s.d. 2.93$) \times 58.71$ (s.d. 4.51$)$ & 1.68 (s.d. 0.10 ) \\
\hline
\end{tabular}

According to analysis of variance test, the difference between mean length/width ratio among $S$. hangoei, P. aciculiferum and P. baicalense from Baikal (pairwise comparison) reliable statistical significance $(P$-value $<0.05)$.

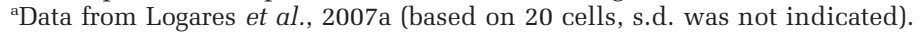



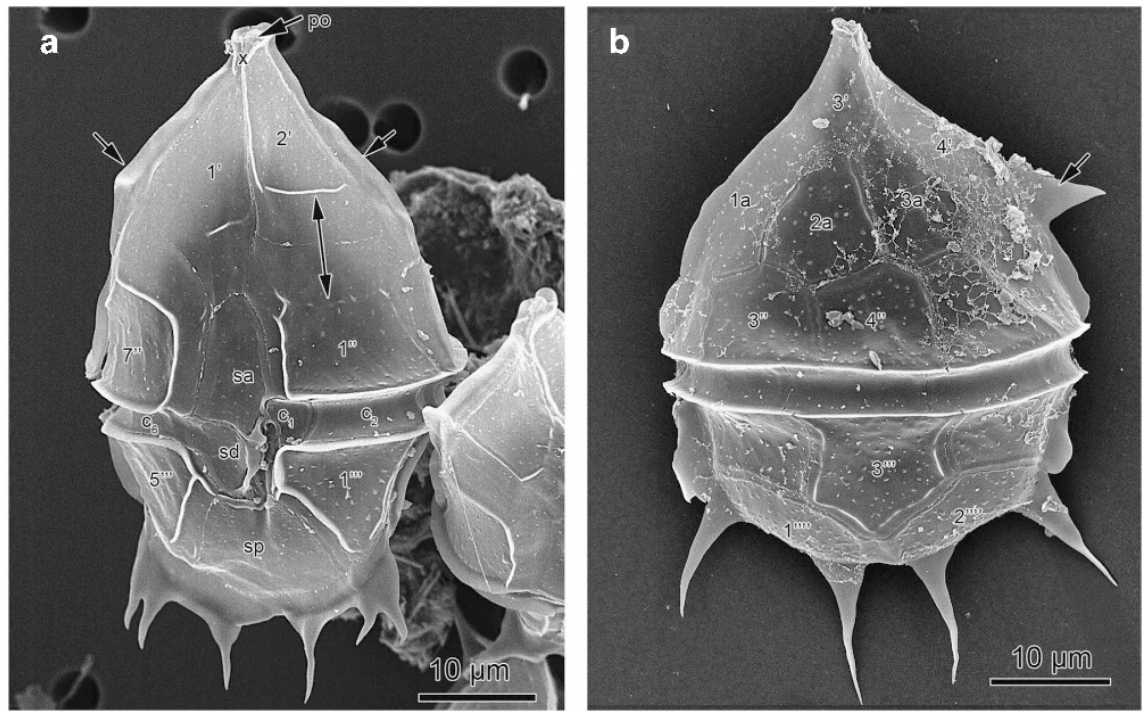

Figure 3 Peridinium baicalense. (a) Cell seen in ventral view. Lateral flanges (arrows) may be mistaken for plate margins. Notice bifurcating antapical horns connected by prominent plate margins and the extremely wide growth bands (double arrow). (b) Cell with lateral horn on plate 4' (arrow), dorsal view.
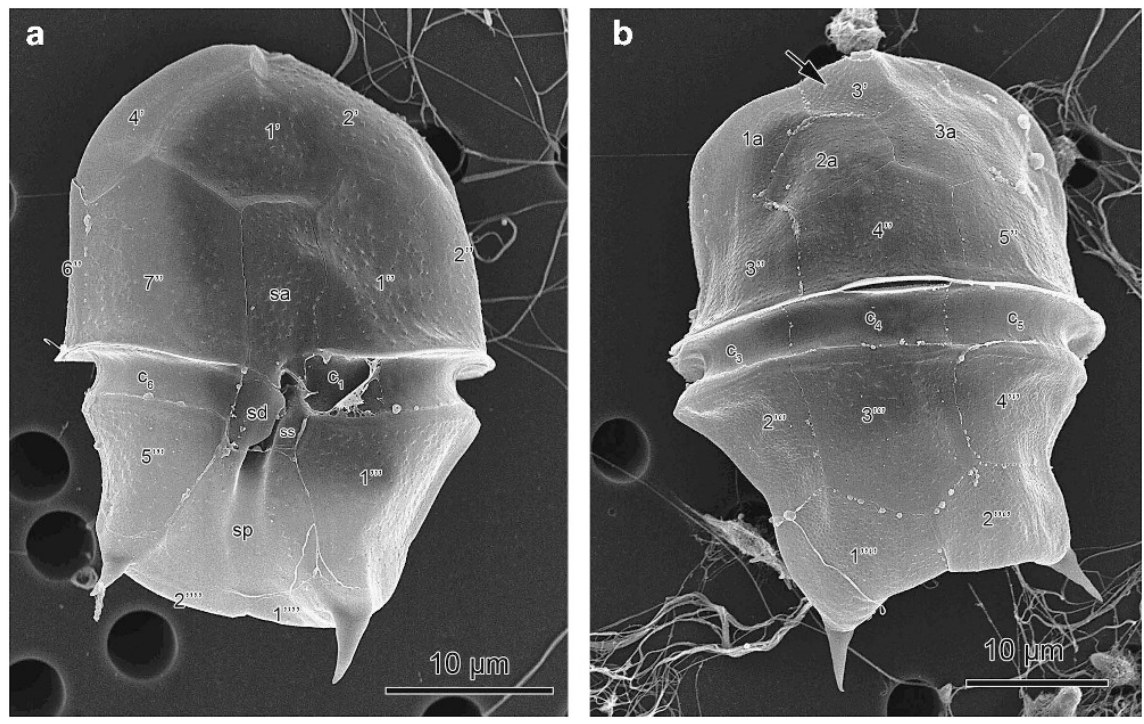

Figure 4 Peridinium euryceps. (a) Cell seen in ventral view; only two antapical horns are present. (b) Dorsal view; the thecal pores seem to be arranged in longitudinal rows (arrow).
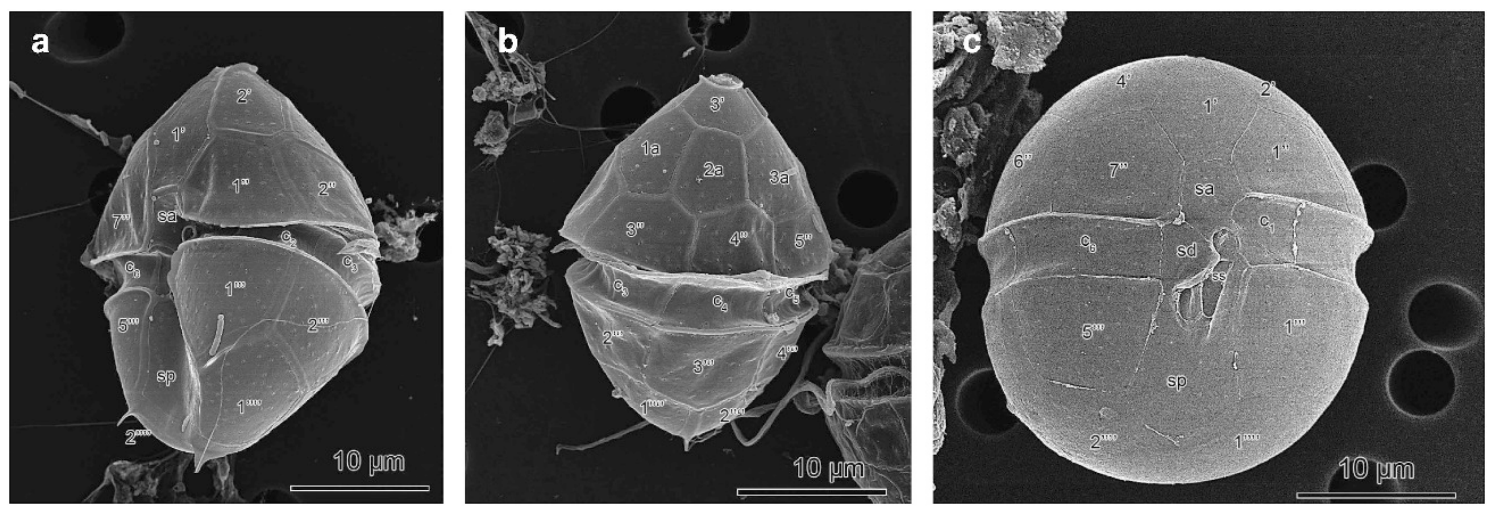

Figure 5 (a) Ventral view of Peridinum aciculiferum, (b) lateral view of P. aciculiferum, and (c) ventral view of Scrippsiella hangoei. 

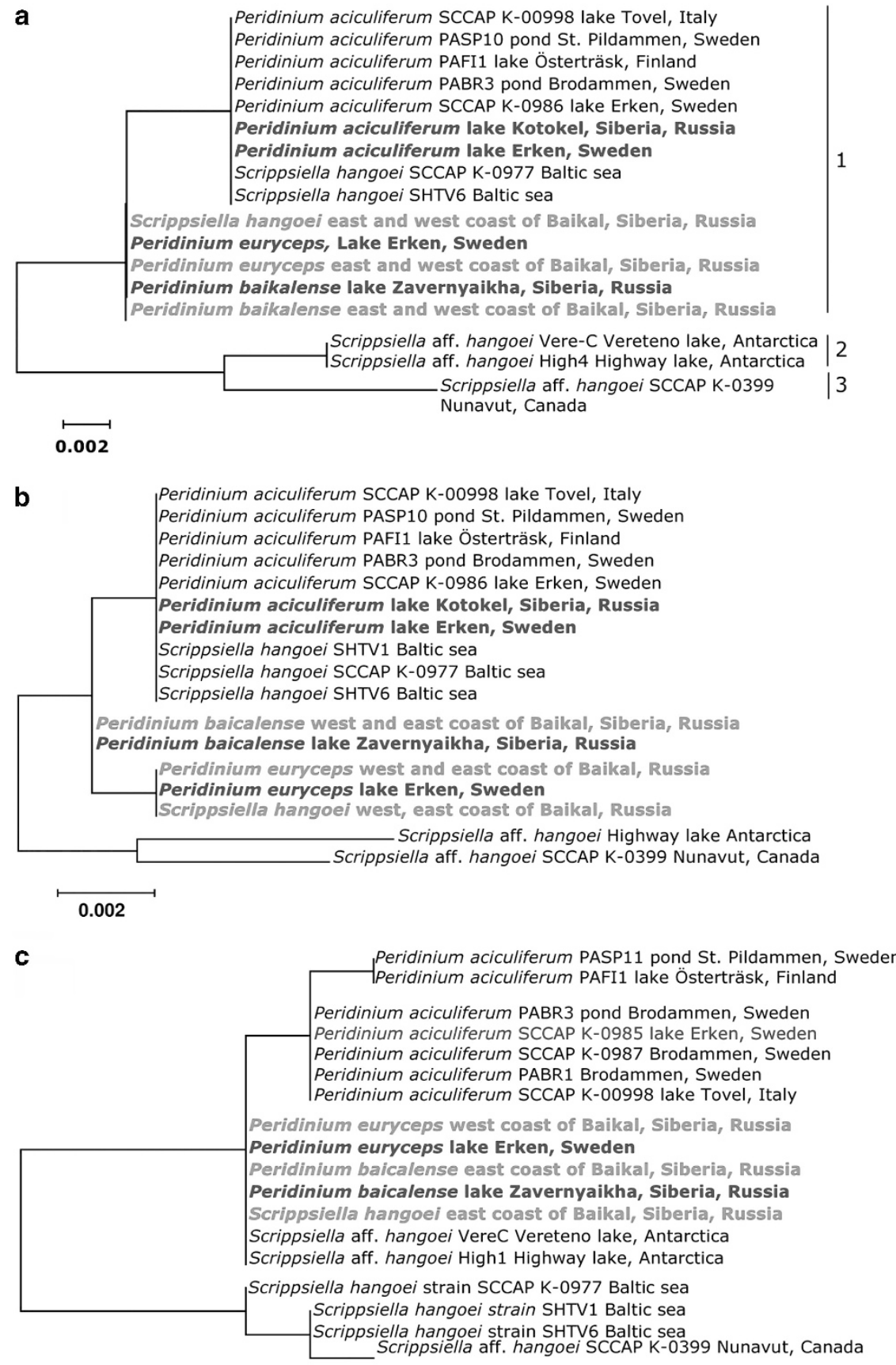

0.002

Figure 6 Midpoint rooted Neighbor-Joining phylograms between: (a) Secondary structure of ITS2 rDNA sequences, based on hemi-CBC distance matrices. Groups 1, 2 and 3 correspond to different ITS2 rDNA secondary structures (see Supplementary Figure S1); (b) ITS2LSU rDNA sequences, based on p-distances; and (c) Partial COB gene sequences, based on $p$-distances. Sequences obtained using singlecell PCR in this study are in bold (red from Lake Baikal, blue from other studied lakes). A full color version of this figure is available at the ISME Journal journal online.

showed that the difference in the entire ITS2-LSU rDNA fragment (772 bp) ranged from $0 \%$ to $0.9 \%$. (Figures 6a and b). The secondary structure of the ITS2 rDNA in S. aff. hangoei from the Antarctic lakes and from the Arctic Ocean, differed from the corresponding structure of the Baltic $S$. hangoei by $3.2 \%$ and $6.5 \%$ in Transfer helix 3 and by $0.8 \%$ and $1.6 \%$ in Transfer helix $\varnothing$, respectively. These differences are explained by hemi-one-sided compensatory base changes (hemi-CBC), that is, an altered pairing in a helix of the secondary structure of the ITS2 RNA. The ITS2 regions of the other studied species had the same secondary structure as the Baltic S. hangoei (Supplementary Figure S2).

$P$. baicalense, $P$. euryceps and Scrippsiella aff. hangoei (from the Antarctic lakes) contained 
identical COB mtDNA fragments (Figure 6c). These fragments differed from the COB mtDNA sequences of $P$. aciculiferum by $0.2-0.3 \%$ and from the Baltic $S$. hangoei by $1.4-1.7 \%$ (Figure 6c). Overall, the genetic differentiation among all $S$. hangoei-like species in the COB mtDNA fragments was low but higher than in the rDNA sequences, with 19 variable sites identified out of the 592 analyzed.

The general patterns based on $p$-distances among the studied sequences (Figure 6) showed that the taxa clustered by species affiliation and not by habitat. The one exception was $S$. hangoei, which is a genetically heterogeneous morphospecies and is found in a range of salinities.

\section{Molecular phylogeny}

The deeper phylogenetic analyses based on two genes (partial SSU and LSU rDNA data) using different optimality criteria resulted in trees with identical topologies (Figure 7). Species of the aciculiferum/hangoei complex are included in the Thoracosphaeraceae family, which contains both calcareous and non-calcareous species, and forms one clade with high statistical support (100 ML; 100 BI, Figure 7). Within this clade, there are four highly supported groups: a Scrippsiella trochoidea-like (not S. hangoei), Stoeckeria-like, Pfiesteria-like, and a $S$. hangoei-like clade (including $S$. hangoei). The species Thoracosphaera heimii did not affiliate with any of these groups. The $P$. aciculiferum-like clade formed a clade with the Pfiesteria- and the Stoeckeria-like clades (95 ML; 100 BI, Figure 7) rather than with the $S$. trochoidea-like clade. Chimonodinium lomnickii also belonged to this clade but did not group with any group within it (Figure 7).

Phylogenetic trees based on the ITS2 and COB fragments confirmed the closeness of the studied dinoflagellates with Pfiesteria-like species (data not shown) in agreement with rDNA tree and an earlier phylogeny by Logares et al. (2007a).

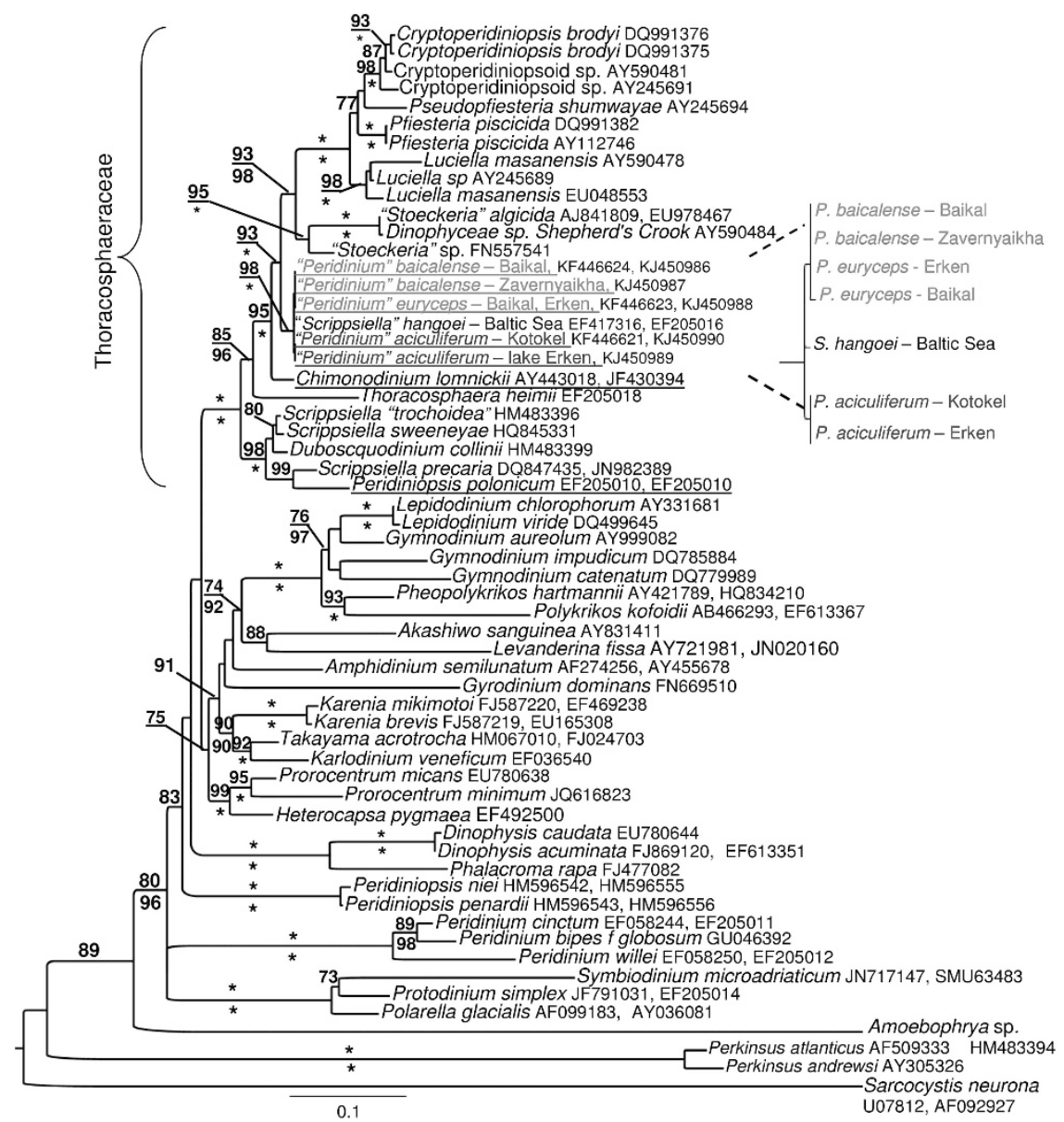

Figure 7 Phylogenetic analysis based on partial SSU rRNA gene and partial LSU rRNA gene. Branch support was inferred using the conservative non-parametric SH-like aLRT test (above vertical lines, asterisk $\left({ }^{*}\right)$ means $100 \%$, values $<90 \%$ were considered as a cutoff for 'good' support and $80-90 \%$ was considered 'moderate' support) and BI posterior probabilities (below vertical line, * means $100 \%$, values $>99 \%$ were considered as 'good' support and 95-99\% was considered as 'moderate' support). Scrippsiella hangoei from Baikal was not included in the analysis, because we did not sequence its SSU rDNA fragment (its ITS2-LSU rDNA fragment is identical to Peridinium euryceps). Sequences obtained from Baikal species are in red, sequences of the species from the other studied lakes are in blue. Freshwater species from Thoracosphaeraceae family are underlined. A full color version of this figure is available at the ISME Journal journal online. 


\section{Discussion}

Here we present an example of a species flock of free-living protists with an unusual discrepancy between morphological and molecular genetic characteristics, suggesting a case of recent evolution and, possibly, adaptive radiation. Originally, a species flock referred to a monophyletic group of at least three species that co-occur and are endemic (Greenwood, 1984), but today the endemicity aspect has been dropped (Schön and Martens, 2004). In the current case, all four morphospecies occur in freshwater lakes, except $S$. hangoei, which has a wide salinity tolerance and is also found in the Baltic Sea and polar oceans. Previously, Logares et al. (2007a, 2008) described a close relationship between the marine $S$. hangoei and the freshwater species $P$. aciculiferum, but here we suggest that these two are part of a bigger story about species radiation.

The studied group of armored dinoflagellate species have previously been described and identified as different species and even genera (Kisselew and Zwetkow, 1935; Larsen et al., 1995; Rengefors and Anderson, 1998; Rengefors and Meyer, 1998; Hansen and Flaim, 2007). All species turned out to have identical SSU rDNA fragments and only very small differences in the LSU rDNA, ITS2 rDNA and mitochondrial COB gene markers. Our results are in stark contrast to the numerous recent studies on protists showing cases of cryptic genetic diversity, where genetic divergence is not reflected in morphological differentiation (for example, Coleman, 2001). We have only found one other similar study in which four marine foraminifera morphospecies were shown to be virtually identical by SSU rDNA and ITS-1 DNA markers (André et al., 2013).

Diversity within the $S$. hangoei/P. aciculiferum group The studied dinoflagellates belong to a single group, based on their plate formula, a feature that is used for species and generic determination in armored dinoflagellates (Steidinger and Tangen, 1997). The plate formula is the pattern of the cellulose plates, which together form the dinoflagellate theca (rigid outer cell covering) (Fensome et al., 1993). Logares et al. (2008) previously showed that $P$. aciculiferum and $S$. hangoei have identical plate patterns. Here we confirm this claim and add $P$. euryceps and $P$. baicalense to the group. However, all four species differ substantially in morphology, including thecal plate shape, general cell shape and the presence or absence of spines (Figures 3-5).

In addition to their morphological differences, the species in question occupy different habitats (Table 2) and at least $S$. hangoei differs in physiology. Logares et al. (2008) showed that, in the laboratory, $S$. hangoei grows equally well at all salinities ranging from 0 to $30 \%$ while $P$. aciculiferum did not grow at salinities $>3 \%$. $S$. hangoei has earlier been found in both brackish (salinity
6\%) and marine cold waters (Larsen et al., 1995; Niels Daugbjerg, personal communication). In the current study, we also observed S. hangoei in Lake Baikal for the first time. To our knowledge, this is the first record of this morphospecies in freshwater. The other species ( $P$. aciculiferum, $P$. euryceps, $P$. baicalense) are known exclusively from freshwater (Kisselew and Zwetkow, 1935; Rengefors and Meyer, 1998; Logares et al., 2008). We confirmed the presence of $P$. euryceps (previously reported only from Lake Erken and Lake Mälaren, Sweden) in Lake Baikal. P. baicalense, which is known as a Lake Baikal endemic, was encountered in one lake (Lake Zavernyaikha), which is hydrologically connected to Lake Baikal. In some lakes (Lake Erken, Lake Baikal) several of the morphospecies occurred together. An earlier report suggested that P. euryceps is a young form of P. baicalense in Baikal (Kisselew and Zwetkow, 1935), but our observations do not support this proposition.

All four morphospecies occasionally produce winter-spring blooms. Their phenotypes are stable and reproducible in different years and locations although we observed some morphological diversity within P. baicalense. Spines may be more or less pronounced or divided into two, and cells may be more or less rounded (for example, Figure 2 A4 and C2). The reversible difference spine length was previously described for the marine dinoflagellate Ceratocorys horrida and Zirbel et al. (2000) associated it with variability in the fluid environment. However, no transitional phenotypes were found between our studied species. Nor were changes in morphology observed in the salinity-tolerance experiments with $P$. aciculiferum and Baltic S. hangoei (Logares et al., 2007a). Cells from the cultures of $P$. baicalense, $S$. hangoei and $P$. aciculiferum have the same morphology as they have in nature (though spines of $P$. baicalense become shorter). Thus there is currently no evidence of phenotypic plasticity yielding different ecotypes in different environments.

Although the phenotypic data suggest at least four different morphospecies, the phylogenetic relationship within the P. aciculiferum-like group could not be resolved as the estimated differentiations among all DNA markers were smaller than normal interspecies differentiation (for example, Litaker et al., 2007). However, the difference exists and is consistent in all replicate sequences within each species. The trees of the rDNA and mitochondrial markers of the studied dinoflagellates disagreed to some extent (Figure 6). In particular, $S$. aff. hangoei from the Antarctic lakes had an identical mitochondrial COB gene fragment sequence to P. baicalense and $P$. euryceps, even though they differed based on the rDNA markers. This finding may be explained by the different mutation rates in the gene fragments. According to Zhang et al. (2005), the evolutionary rate for mtDNA is considered to be low for dinoflagellates and the COB mtDNA marker 
is therefore relatively conservative. Logares et al. (2008) concluded that ancient COB polymorphism could persist in the dinoflagellate populations. Thus COB variations may show the historical origins of the groups, while rDNA represents how many substitutions were accumulated after isolation. In particular, Baikal P. baicalense and P. euryceps, as well as Antarctic $S$. aff. hangoei, could have originated from ancestral strains with the same COB haplotype. This haplotype has not had enough time to evolve, while the isolation of $S$. hangoei in Antarctica has allowed for accumulation of substitutions in less conservative parts of its genome (such as the ITS2 and D1-D3 domains of the LSU rDNA). Nevertheless, it is also possible that the 'lineage sorting' type of differences between the rDNA and COB trees originated via recombination/ duplication processes in the cells.

According to both the rDNA data (ITS2, LSU, SSU) and the COB gene fragment, $P$. euryceps from Lake Baikal and from Lake Erken are genetically identical. P. aciculiferum is also genetically identical both in European lakes and the Asian Lake Kotokel. These results indicate that the two morphospecies do not form isolated lineages at the observed locations. Until now, P. baicalense has not been found outside the Baikal region, where this morphospecies is homogeneous based on the studied DNA markers. In contrast, the morphospecies $S$. hangoei (including S. aff. hangoei) has small intraspecific genetic differences among the locations (Figure 6). One explanation could be that cryptic species occur within the $S$. hangoei morphospecies or that it is a single cosmopolitan species with isolated populations.

Coleman (2009) recently showed that differences in ITS2 rDNA secondary structure can predict failure of crossing between organisms and can thus be used as one criterion to differentiate between species. We found small differences in the ITS2 secondary structure among arctic Scrippsiella aff. hangoei, S. aff. hangoei from Antarctic lakes and Baltic S. hangoei. This suggests that the morphospecies $S$. hangoei could represent at least two or three cryptic species. For all freshwater species, the ITS2 secondary structure is identical to that of the Baltic S. hangoei. To confirm that we have independent species we would need to investigate whether the different species can interbreed. However, the biological species concept is problematic, as sexual reproduction of protists can be difficult to induce in laboratory experiments. As a whole, we presently consider the studied dinoflagellates to represent four closely related morphospecies, because their morphological difference is not in doubt.

Relationship between the S. hangoei/P. aciculiferum group and other dinoflagellates

Even though the phylogenetic relationships within the studied group could not be resolved, it was possible to determine its position among other dinoflagellate groups. Previous phylogenetic studies of the 'hangoei-aciculiferum' complex supported their evolutionary closeness to Pfiesteria-like species, with high Bayesian posterior probabilities but with low bootstrap support (for example, Logares et al., 2008). In the current analysis, we obtained a much higher level of statistical support for this clade (Figure 7), although more related species need to be included for a better resolution of the relationships within the family Thoracosphaeraceae. Nevertheless, the stability of the whole clade is shown both in this and previous studies (for example, Gottschling et al., 2012). According to both the morphology (thecal plate pattern) and phylogeny, the studied group does not belong to neither the genus Peridinium nor Scrippsiella, and the generic affiliation needs to be revised.

Based on the scheme by Logares et al. (2009), we concluded that members of the Thoracosphaeraceae clade are examples of dinoflagellates that succeeded to overcome the salinity boundary recently: several closely related marine, brackish, and freshwater dinoflagellates are present in different parts of this clade (Figure 7, underlined species). In addition, the UniFrac test did not show significant difference between marine and freshwater species from this clade. Moreover, the freshwater Tyrannodinium edax is also known to be a close relative of the brackish or marine Pfiesteria-like species (Calado et al., 2009, as Tyrannodinium berolinense). Thus at least five freshwater species are interspersed among the marine/brackish species. This is atypical, as most groups of freshwater dinoflagellates are phylogenetically distinct from the marine groups (Logares et al., 2007b), a pattern which is also true for many other protists (for example, Alverson et al., 2007; Bråte et al. 2010). Based on the current phylogenetic trees, it is not possible to determine whether $S$. hangoei was originally a marine species or whether it had a freshwater ancestor that recolonized the marine environment.

\section{Adaptive radiation?}

Here we found that the 'aciculiferum/hangoei' group consists of at least four recently diverged species, which make up a species flock. This species flock could be a case of rapid adaptive radiation, in which an ancestor has rapidly diverged into a multitude of new forms in response to changes in the environment (for example, Dolph, 2000). In adaptive radiation, the new species should show phenotypic adaptation and display different morphological and physiological traits. In the current case, the species have both morphological differences and differences in tolerance to salinity (not tested for P. baicalense and $P$. euryceps) and show both sympatry and allopatry. Although the evidence to date suggests recent adaptive radiation, we cannot rule out nonadaptive radiation (for example, Wilke et al. 2010). 
Changes in regulatory parts of the genome, switching of ontogenetic programs and changes in gene expression may all theoretically lead to such new phenotypes. For example, Jones et al. (2012) showed that regulatory changes appear to predominate in the set of loci underlying marine-freshwater evolution in stickleback fish species flock. However, accumulation of differences in neutral DNA markers requires much longer time than changes in gene regulation. This could explain the absence of pronounced differences in the variable but neutral DNA markers among the microorganisms in our species flock.

The history of the lakes inhabited by the hangoei/ aciculiferum species flock is congruent with its recent radiation as indicated by the small differences in the DNA markers. Most (74\%) freshwater lakes in the world were formed by glacial processes and are thus $<20000$ years old (Kalff, 2002). Lake Baikal, in contrast, is $>25$ million years old (Mats et al., 2011), making recent colonization of dinoflagellates appear contradictory. However, dramatic changes have occurred during the geological evolution of Lake Baikal. The most severe change lasted from 3.5 Ma to about 0.15 Ma years ago, when the relatively shallow lake became extremely deep due to various tectonic events (Mats et al., 2011). At this time mountainous glaciations also developed (Mats et al., 2011). This led to the extinction of many species and at the same time to a high level of speciation. As a result, most of the modern pelagic community of Baikal is actually young (Karabanov et al., 2000). In particular, some of the Baikal multicellular endemics have a relatively recent origin ( $\leqslant 2-5$ million years) according to genetic data (Mats et al., 2011). Moreover, the modern diatom community formed $<11000$ years ago (Khursevich et al., 2001). According to phylogenetic data, the endemic dinoflagellate Gymnodinium baicalense appeared in Lake Baikal no earlier than during the Pliocene-Pleistocene glaciations (Annenkova, 2013). These observations support the opinion expressed by Dorogostaysky (1923) that many Baikal endemics are relatively young and have high rates of speciation (in certain cases, rapid radiation). During the last cooling period (1.8-0.15 Ma ago), certain ecological niches in the Baikal plankton may therefore have been empty. Immigrants such as $S$. hangoei-like dinoflagellates could have reached Baikal and been able to colonize (and later possibly diversify). This 'ecological factor' may have helped a S. hangoeilike ancestor to adapt to the Lake Baikal habitat even if the salinity was not optimal for it.

\section{What factors could induce the origin of the 'species} flock'?

Barriers to gene flow between lineages can be introduced by ecological and/or geographical factors. Because of the co-occurrence of several morphospecies within the hangoei/aciculiferum species complex, sympatric (ecological) speciation seems more likely, although allopatric (geographical) speciation following sympatry cannot be ruled out. For instance, $P$. aciculiferum coexists with $P$. euryceps in Lake Erken, which was connected to the brackish Baltic Sea (where S. hangoei occurs) up until 3000 years ago (Ekman and Fries, 1970). Moreover, S. hangoei, P. euryceps and P. baicalense coexist in Lake Baikal.

Logares et al. (2008) suggested differences in water salinity as the main driver of speciation between $P$. aciculiferum and S. hangoei. However, this hypothesis does not explain the presence of $S$. hangoei in freshwater Lake Baikal and its absence in Lake Erken. Lake Baikal is unique, even though it is a freshwater lake its other features are closer to a marine environment (that is, huge water volume that stabilizes physical and chemical features). This may be critical for $S$. hangoei survival. Further, as mentioned above, ecological factors (for example, the absence of competitors or grazers because of the species extinction in the Pleistocene (Mats et al., 2011)) could have promoted $S$. hangoei's initial success in Baikal. Interestingly, in the saline environment we only observed a single morphotype, $S$. hangoei, which at the same time was genetically heterogeneous. In contrast, pronounced morphological variation was found among the true freshwater morphospecies ( $P$. aciculiferum, $P$. euryceps, P. baicalense).

\section{Conclusions}

Most examples of rapid radiation in nature involve large animals and plants, and little is known about this phenomenon in free-living protists. Here we observed a species flock of protists that has evolved recently and rapidly. We propose that this is a case of adaptive radiation as all observed morphologically distinct taxa are extremely similar in DNA markers, sometimes co-occur, but have distinct different phenotypes. Further studies are needed to investigate whether the different morphospecies have adapted to different ecological niches.

\section{Conflict of Interest}

The authors declare no conflict of interest.

\section{Acknowledgements}

Financial support for this work was provided by The Swedish Research Council grant 621-2009-5324 to KR, a Swedish Institute Scholarship to NA and Project no. 1204-31802-mol_a of the Russian Foundation for Basic Research to NA. We thank the Institute for System Dynamics and Control Theory SB RAS for providing access to the mvs-1000/16 cluster. We are grateful to I Khanaev and I Tomberg for their help in sample collection. Special thanks to NV Annenkova's family for their help 
during expeditions and constructive suggestions on an earlier version of the article by the Plankton Ecology Group at the Aquatic Ecology Unit, Department of Biology, Lund University, Lund, Sweden. Several anonymous reviewers are thanked for their help in improving earlier versions of the manuscript.

\section{References}

Alverson AJ, Jansen RK, Theriot EC. (2007). Bridging the Rubicon: phylogenetic analysis reveals repeated colonizations of marine and fresh waters by thalassiosiroid diatoms. Mol Phyl Evol 45: 193-210.

André A, Weiner A, Quillévéré F, Aurahs R, Morard R, Douady CJ et al. (2013). The cryptic and the apparent reversed: lack of genetic differentiation within the morphologically diverse plexus of the planktonic foraminifer Globigerinoides sacculifer. Paleobiology 39: $21-39$.

Anisimova M, Gascuel O. (2006). Approximate likelihood ratio test for branches: a fast, accurate and powerful alternative. Syst Biol 55: 539-552.

Annenkova NV. (2013). Phylogenetic relations of the dinoflagellate Gymnodinium baicalense from Lake Baikal. CEJB 8: 366-373.

Annenkova NV, Belikov SI. (2010). Detection of the dinoflagellates which are phylogenetically close to Pfiesteriaceae family in Baikal Lake. Water Chem Ecol 11: $40-46$.

Annenkova NV, Lavrov DV, Belikov SI. (2011). Dinoflagellates associated with freshwater sponges from the ancient Lake Baikal. Protist 162: 222-236.

Bråte J, Logares R, Berney C, Ree DK, Klaveness D, Jakobsen KS et al. (2010). Freshwater Perkinsea and marine-freshwater colonizations revealed by pyrosequencing and phylogeny of environmental rDNA. ISME J 4: 1144-1153.

Calado AJ, Craveiro SC, Daugbjerg N, Moestrup Ø. (2009). Description of Tyrannodinium gen. nov., a freshwater dinoflagellate closely related to the marine Pfiesterialike species. J Phycol 45: 1195-1205.

Coleman AW. (2001). Biogeography and speciation in the Pandorina/Volvulina (Chlorophyta) superclade. J Phycol 37: 836-851.

Coleman AW. (2009). Is there a molecular key to the level of "biological species" in eukaryotes? A DNA guide. Mol Phyl Evol 50: 197-203.

Criscuolo A. (2011). morePhyML: Improving the phylogenetic tree space exploration with PhyML 3. Mol Phyl Evol 61: 944-948.

Darriba D, Taboada GL, Doallo R, Posada D. (2012). jModelTest 2: more models, new heuristics and parallel computing. Nat Methods 9: 772.

Daugbjerg N, Hansen G, Larsen J, Moestrup Ø. (2000). Phylogeny of some of the major genera of dinoflagellates based on ultrastructure and partial LSU rDNA sequence data, including the erection of three new genera of unarmoured dinoflagellates. Phycologia 39: 302-317.

Dolph S. (2000). The Ecology of Adaptive Radiation. Oxford University Press: Oxford, UK.

Dorogostaysky V. (1923). Vertical and horizontal distribution of Lake Baikal fauna. Proc Irkutsk State Univ Irkutsk 4: 103-130.
Ekman P, Fries M. (1970). Studies of sedimental from Lake Erken, eastern central Sweden. Geol För Stockh Förh 92: 214-224.

Fensome RA, Taylor FJR, Norris G, Sarjeant WAS, Wharton DI, Williams GL. (1993). A classification of living and fossil dinoflagellates. Micropaleontology 7. Sheridan Press: Hanover, Pennsylvania, USA.

Gavrilets S, Losos JB. (2009). Adaptive rRadiation: contrasting theory with data. Science 323: 732-737.

Gelman A, Rubin DB. (1992). Inference from interative simulation using multiple sequences. Stat Sci 7: 457-511.

Gómez P, Buckling A. (2013). Real-time microbial adaptive diversification in soil. Ecol Lett 16: 650-655.

Gottschling M, Soehner S, Zinssmeister C, John U, Plötner J, Schweikert M et al. (2012). Delimitation of the Thoracosphaeraceae (Dinophyceae), including the calcareous dinoflagellates, based on large amounts of ribosomal RNA sequence data. Protist 163: 15-24.

Grant PR, Grant BR. (2011). How and Why Species Multiply: the Radiation of Darwin's Finches. Princeton University Press: Princeton, NJ, USA.

Greenwood PH. (1984). What is a species flock? In: Echelle AA, Kornfield I (eds). Evolution of Fish Species Flocks. Univ. Maine at Orono Press: Orono, Maine, USA, pp 13-19.

Hall TA. (1999). BioEdit: a user-friendly biological sequence alignment editor and analysis program for Windows 95/98/NT. Nucleic Acids Symp 4: 95-98.

Hansen G, Flaim G. (2007). Dinoflagellates of the Trentino Province, Italy. Limnol 66: 107-141.

Harington CR. (2008). The evolution of arctic marine mammals. Ecol Appl 18: S23-S40.

Hunt DE, David LA, Gevers D, Preheim SP, Alm EJ, Polz MF. (2008). Resource partitioning and sympatric differentiation among closely related bacterioplankton. Science 320: 1081-1085.

Jones FC, Grabherr MG, Chan YF, Russell P, Mauceli E, Johnson J et al. (2012). The genomic basis of adaptive evolution in threespine sticklebacks. Nature 484: 55-61.

Kalff J. (2002). Limnology: Inland Water Ecosystems. Prentice-Hall: Upper Saddle River, NJ, USA.

Karabanov EV, Prokopenko AA, Williams DF, Khursevich GK. (2000). A new record of Holocene climate change from the bottom sediments of Lake Baikal. Paleogeogr Paleoecol 156: 211-224.

Kasuga T, White TJ, Koenig G, Mcewen J, Restrepo A, Castañeda E et al. (2003). Phylogeography of the fungal pathogen Histoplasma capsulatum. Mol Ecol 12: 3383-3401.

Katoh K, Toh H. (2010). Parallelization of the MAFFT multiple sequence alignment program. Bioinformatics 26: 1899-1900.

Khursevich GK, Karabanov EB, Prokopenko AA, Williams D, Kuzmin M, Fedenia S et al. (2001). Detailed diatom stratigraphy of Lake Baikal sediments in the Bryunes Epoch and climatic factors of speciation. Geol Geofiz 42: 108-129.

Kisselew JA, Zwetkow WN. (1935). Zur Morphologie und Ökologie von Peridinium baicalense n. sp. Beih Bot Centralbl 53: 518-524.

Kozhova OM, Izmest'eva LR (eds). (1998). Lake Baikal: Evolution and Biodiversity. Backhuys Publications: Leiden, The Netherlands.

LaJeunesse TC. (2005). 'Species' radiations of symbiotic dinoflagellates in the Atlantic and Indo-Pacific since the Miocene-Pliocene transition. Mol Biol Evol 22: 570-581. 
Larsen J, Kuosa H, Ikävalko J, Kivi K, Hällfors S. (1995) A redescription of Scrippsiella hangoei (Schiller) comb. nov-a red tide dinoflagellate from the Northern Baltic. Phycologia 34: 135-144.

Lin S, Zhang H, Hou Y, Zhuang Y, Miranda L. (2009). High-level diversity of dinoflagellates in the natural environment, revealed by assessment of mitochondrial cox1 and cob genes for dinoflagellate DNA barcoding. Appl Environ Microbiol 75: 1279-1290.

Litaker RW, Vandersea MW, Kibler SR, Reece KS, Stokes NA, Lutzoni FM et al. (2007). Recognizing dinoflagellate species using its rDNA sequences. J Phycol 43: 344-355.

Logares R, Bråte J, Bertilsson S, Clasen JL, Shalchian-Tabrizi K, Rengefors K. (2009). Infrequent marine-freshwater transitions in the microbial world. Trends Microbiol 17: 414-422.

Logares R, Daugbjerg N, Boltovskoy A, Kremp A, Laybourn-Parry J, Rengefors K. (2008). Recent evolutionary diversification of a protist lineage. Environ Microbiol 10: 1231-1243.

Logares R, Rengefors K, Kremp A, Shalchian-Tabrizi K, Boltovskoy A, Tengs T et al. (2007a). Phenotypically different microalgal morphospecies with identical ribosomal DNA: a case of rapid adaptive evolution? Microb Ecol 53: 549-561.

Logares R, Shalchian-Tabrizi K, Boltovskoy A, Rengefors K. (2007b). Extensive dinoflagellate phylogenies indicate infrequent marine-freshwater transitions. Mol Phyl Evol 45: 887-903.

Lozupone C, Hamady M, Knight R. (2006). UniFrac-an online tool for comparing microbial community diversity in a phylogenetic Context. BMC Bioinformatics 7: 371.

MacLean RC. (2005). Adaptive radiation in microbial microcosms. J Evol Biol 18: 1376-1384.

Martiny JBH, Bohannan BJM, Brown JH, Colwell RK, Fuhrman JA, Green JL et al. (2006). Microbial biogeography: putting microorganisms on the map. Nat Rev Microbiol 4: 102-112.

Mats VD, Sherbakov DYu, Efimova IM. (2011). Late Cretaceous-Cenozoic history of Lake Baikal depression and formztion of the unique biodiversity. Stratigr Geol Correl 19: 404-423.

Montresor M, Sgrosso S, Procaccini G, Kooistra WHCF. (2003). Intraspecific diversity in Scrippsiella trochoidea (Dinophyceae): evidence for cryptic species. Phycologia 42: 56-70.

Pfennig DW, Wund MA, Snell-Rood EC, Cruickshank T, Schlichting CD, Moczek AP. (2010). Phenotypic plasticity's impacts on diversification and speciation. Trends Ecol Evol 25: 459-467.

Popovskaya GI. (1991). Phytoplankton of Lake Baikal and its long-term changes (1958-1990). PhD thesis. Academy of Sciences, Siberian Branch, Central Siberian Botanical Garden, Novosibirsk, Russia.
Rengefors K, Anderson DM. (1998). Environmental and endogenous regulation of cyst germination in two fresh-water dinoflagellates. J Phycol 34: 568-577.

Rengefors K, Laybourn-Parry J, Logares R, Marshall WA, Hansen G. (2008). Marine-derived dinoflagellates in Antarctic saline lakes: community composition and annual dynamics. J Phycol 44: 592-604.

Rengefors K, Meyer B. (1998). Peridinium euryceps sp. nov. (Peridiniales, Dinophyceae), a cryophilic dinoflagellate from Lake Erken, Sweden. Phycologia 37: 284-291.

Ronquist F, Huelsenbeck JP. (2003). MrBayes 3: Bayesian phylogenetic inference under mixed models. Bioinformatics 19: 1572-1574.

Schluter D. (2000). The Ecology of Adaptive Radiation. Oxford University Press: Oxford, UK.

Schön I, Martens K. (2004). Adaptive, pre-adaptive and non-adaptive components of radiations in ancient lakes: a review. Org Divers Evol 4: 137-156.

Seehausen O. (2006). African cichlid fish: a model system in adaptive radiation research. Proc $R$ Soc $B$ 273: 1987-1998.

Sherbakov DYu. (1999). Molecular phylogenetic studies on the origin of biodiversity in Lake Baikal. Trends Ecol Evol 14: 92-94.

Steidinger KA, Tangen K. (1997). Dinofllagellates. In: Tomas C (ed). Identifying Marine Phytoplankton. Academic Press: San Diego, CA, USA 1387-1584.

Tamura K, Peterson D, Peterson N, Stecher G, Nei M, Kumar S. (2011). MEGA5: Molecular Evolutionary Genetics Analysis using maximum likelihood, evolutionary distance, and maximum parsimony methods. Mol Biol Evol 28: 2731-2739.

Tanichev AI, Bondarenko NA. (1995). Free-living flagellates. In Timoshkin OA (ed). The Atlas and Index of Pelagiobionts of Baikal. Nauka: Novosibirsk, Russia.

Timoshkin OA. (1999). Biology of Lake Baikal: "White spots" and progress in research. Berliner Geowiss Abh E 30: 333-348.

Wilke T, Benke M, Brändle M, Albrecht C, Bichain J-M. (2010). The neglected side of the coin: non-adaptive radiations in spring snails (Bythinella spp.). In: Glaubrecht M (ed). Evolution in Action. Case studies in Adaptive Radiation, Speciation and the Origin of Biodiversity. Springer: Dordrecht, The Netherlands, pp 551-578.

Wolf M, Friedrich J, Dandekar T, Müller T. (2005). CBCAnalyzer: inferring phylogenies based on compensatory base changes in RNA secondary structures. In Silico Biol 5: 291-294.

Zhang H, Bhattacharya D, Lin S. (2005). Phylogeny of dinoflagellates based on mitochondrial cytochrome b and nuclear small subunit rDNA sequence comparisons. J Phycol 41: 411-420.

Zirbel MJ, Veron F, Latz MI. (2000). The reversible effect of flow on the morphology of Ceratocorys horrida (Peridiniales, Dinophyta). J Phycol 36: 46-58.

Supplementary Information accompanies this paper on The ISME Journal website (http://www.nature.com/ismej) 